\title{
ПРЕЗЕНТАЦІЯ ПРОЕКТУ ДЕРЖАВНОГО СТАНДАРТУ БАЗОВОЇ СЕРЕДНЬОӦ ОСВІТИ: ЧИМ НОВИЙ СТАНДАРТ ВІДРІЗНЯЄТЬСЯ ВІД ПОПЕРЕДНІХ?
}

Bucmyn на серпневій конференції 2020 (онлайн) «Освіта в умовах пандемії: як організувати навчальний рік 2020-2021», 18 серпня 2020 р. https://doi.org/10.37472/2707-305X-2020-2-2-11-5

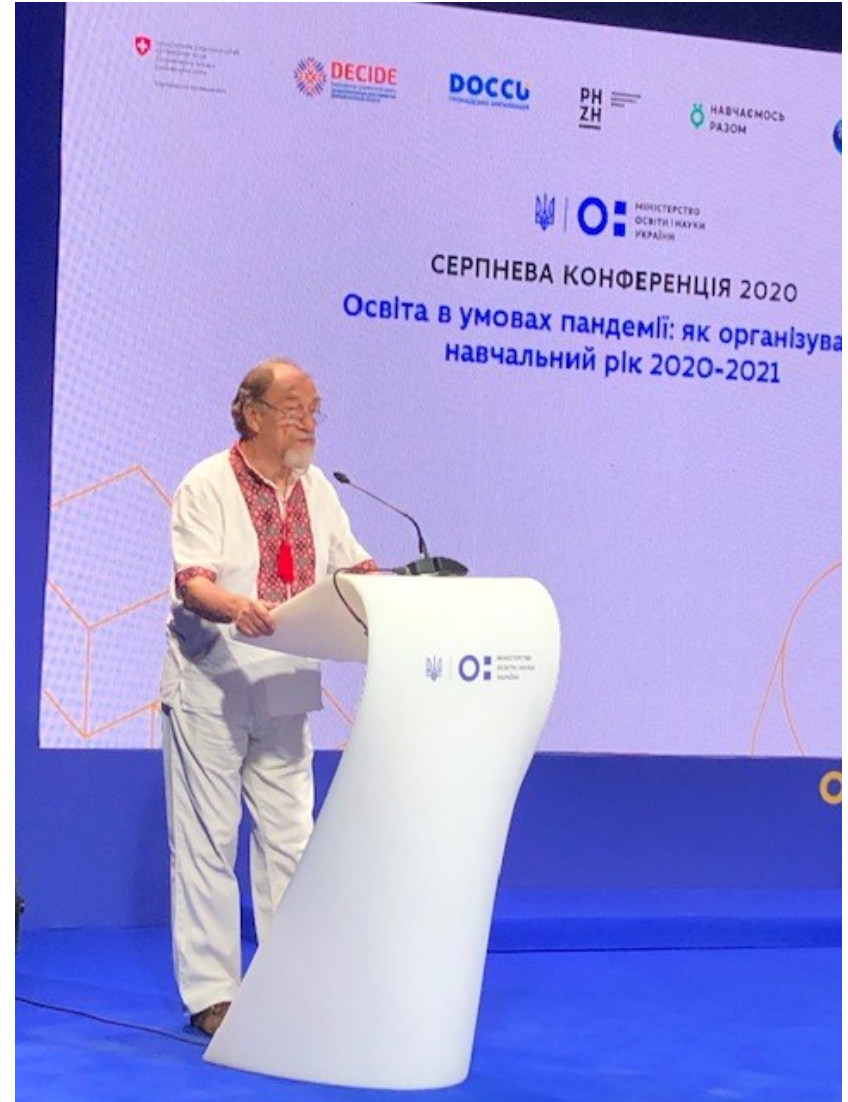

Шановні освітяни!

Сьогодні ми презентуємо проєкт Державного стандарту базової середньої освіти, який $€$ вже третьою генерацією державних стандартів загальної середньої освіти. Природно виникає питання: Чим цей стандарт відрізняється від двох nonередніх?

Переді мною Роман Шиян, керівник робочої групи, окреслив основні засади проєкту стандарту. Я ж закцентую увагу на відмінностях даного
ЛЯШЕНКО Олександр Іванович доктор педагогічних наук, професор, дійсний член (академік) НАПН України, академіксекретар Відділення загальної середньої освіти Національної академії педагогічних наук України, науковий консультант робочої групи з розроблення стандартів загальної середньої освіти, м. Київ, Україна

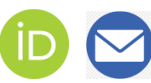

Анотація. Під час презентації проєкту Державного стандарту базової середньої освіти на серпневій конфререниії 2020 року окреслено основні відмінності нинішнього проєкту від освітніх стандартів попередніх поколінь, а саме: компетентнісний підхід, що грунтується на ключових компетентностях; цілісне бачення поступу дитини в навчанні від 1 до 12 класу; надання більшої академічної свободи закладам освіти при створенні власних освітніх програм; залучення до роботи представників різних категорій освітян і науковців, що сприяло креативності і творчій ініціативності розробників стандарту та обгрунтованості запропонованих рішень.

Ключові слова: базова середня освіта; державний стандарт базової середньої освіти; ключові компетентності; компетентнісний підхід; результати навчання.

проєкту від попередніх поколінь державних стандартів повної загальної середньої освіти.

По-перше, це покладання компетентнісного підходу в основу побудови стандарту. Мені можуть дорікнути, що цей підхід використовувався раніше, в попередньому стандарті. Дійсно, це так. Проте в тому стандарті все ґрунтувалося на предметних компетентностях: спочатку окреслювався предметний зміст освітньої галузі і вже на підставі його визначалися вимоги до навчаль- 
них досягнень учнів. Не освітні результати, яких має досягнути випускник школи, впливали на добір змісту, а навпаки, зміст предметів чи освітніх галузей, запропонований розробниками освітнього стандарту, по суті суб'єктивний за способом його визначення, регулював вимоги до результатів навчання учнів. Нинішній проєкт стандарту ґрунтується не на предметних, а на ключових компетентностах та освітніх результатах, якими має оволодіти кожний випускник школи на певних етапах навчання, загалом кожна людина, щоб бути успішною в житті. Причому в новому стандарті освітні результати визначаються не лише за рівнями освіти, як було раніше, а й за циклами навчання, які враховують вікові особливості учнів і специфіку освітнього процесу на даному етапі навчання. Для базової середньої освіти це 5-6 класи і 7-9 класи.

По-друге, розроблення стандарту передбачало цілісне бачення поступу дитини в навчанні від 1 до 12 класу. Тому в новому стандарті визначався компетентнісний потенціал кожної освітньої галузі у забезпеченні формування усіх без винятку ключових компетентностей. У попередніх стандартах початкова школа, наприклад, декларувала свої освітні цілі окремо, без урахування потреб повної загальної середньої освіти, у тому числі наступного рівня - базової середньої освіти. Тому в навчальних програмах основної школи спостерігалося дублювання навчального матеріалу або ще гірше - відсутність логічного зв'язку в розгортанні змісту того чи іншого предмета. Новим стандартом забезпечується наступність між початковою і базовою середньою освітою. Так само в стандарті наступного рівня вона буде забезпечена між базовою і профільною середньою освітою.

По-mpemє, на відміну від попередніх стандартів у нинішньому проєкті надається більще академічної свободи закладам освіти, оскільки в Базовому навчальному плані для кожної освітньої галузі зазначається мінімальна і рекомендована кількість навчальних годин за циклами навчання. Це надає можливість школам при створенні власних освітніх програм варіювати в обсягах навчального навантаження залежно від освітніх потреб та інтересів учнів. Попередні стандарти жорстко регламентували розподіл годин між освітніми галузями в інваріантній частині Базового плану і надавали академічну свободу лише за рахунок варіативного складника.

Нарешті, четверте, це творча атмосорера $i$ креативний підхід, які панували в колективі розробників стандарту. У роботі над цим документом брали участь і вчителі ma методисти, які привносили свій інноваційний практичний досвід освітньої діяльності, і викладачі вишів та науковці, зокрема Національної академії педагогічних наук України, які реалізували свої наукові напрацювання в обґрунтуванні методології стандарту, і зарубіжні експерти та широка освітянська й батьківська громадськість, які уважно слідкували за нашою роботою, допомагали порадами і не давала нам схибити. Такий творчий симбіоз дав, на нашу думку, позитивний результат у вигляді проєкту стандарту, який презентується сьогодні незабаром буде прийнятий Кабінетом Міністрів України.

Попереду ще багато роботи щодо його впровадження, розроблення типових освітніх програм і модельних навчальних програм, підготовки вчителів до його реалізації, навчально-методичного забезпечення тощо.

\section{СПИСОК ВИКОРИСТАНИХ ДЖЕРЕЛ}

Закон України. (2020, 16 січня). Про повну загальну середню освіту (463-IX). https://zakon.rada.gov.ua/laws/ show $/ 463-20$

Міністерство освіти і науки України. (2019, 10 грудня). Про утворення робочої групи з розроблення Державного стандарту базової середньої освіти (1533) https://mon.gov.ua/ua/npa/pro-utvorennya-robochoyigrupi-z-rozroblennya-derzhavnogo-standartu-bazovoyiserednoyi-osviti

Міністерство освіти і науки України. (2020, 4 березня). МОН пропонує для громадського обговорення проєкт Державного стандарту базової середньої освimu. https://mon.gov.ua/ua/news/mon-proponuyedlya-gromadskogo-obgovorennya-proyekt-derzhavnogostandartu-bazovoyi-serednoyi-osviti

Міністерство освіти і науки України. (2020, 12 червня). Міністерство освіти і науки України пропонує для громадського обговорення проєкт Державного стандарту базової середньої освіти. https://mon.gov.ua/ ua/news/ministerstvo-osviti-i-nauki-ukrayini-proponuyedlya-gromadskogo-obgovorennya-proyekt-derzhavnogostandartu-bazovoyi-serednoyi-osviti

Міністерство освіти і науки України. (2020, 18 серпня). Серпнева конференція 2020. https://mon.gov.ua/ua/ osvita/zagalna-serednya-osvita/konferenciyi/serpnevakonferenciya-2020 


\section{PRESENTATION OF THE DRAFT STATE STANDARD OF LOWER SECONDARY EDUCATION: HOW DOES THE NEW STANDARD DIFFER FROM THE PREVIOUS ONES? \\ Speech at the August 2020 Conference (online) "Education under the Pandemic: How to Organize the 2020/21 School Year", August 18, 2020} DSc in Education, Professor, Full Member (Academician) of NAES of Ukraine, Academician Secretary of the Division of General Secondary Education, National Academy of Educational Sciences of Ukraine, Scientific Consultant of the Working Group on Designing the State Standards of General Secondary Education, Kyiv, Ukraine

Abstract. The main differences between the current draft State Standard of Lower Secondary Education and the education standards of previous generations were outlined during the Standard's presentation at the August 2020 Conference, i.e.: competence-based approach; a holistic vision of the child's progress in learning from the 1st to the 12th grades; provision of greater academic freedom to education institutions in creating their own educational programs; involvement of representatives of different categories of educators and researchers, that contributed to the creativity and creative initiativeness of the standard's developers and validity of the proposed solutions.

Keywords: lower secondary education; the State Standard of Lower Secondary Education; key competences; competence-based approach; learning outcomes. 